\title{
Sopeuttavaa sivistystyötä?
}

JYRI MANNINEN

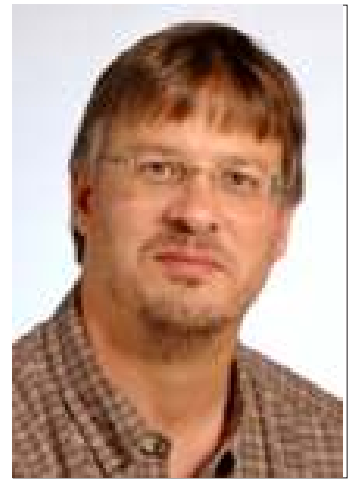

Välittömien oppimistulosten lisäksi vapaalla sivistystyöllä on yksilön, yhteisön ja yhteiskunnan kannalta myös laajempia vaikutuksia, kuten henkinen hyvinvointi ja itsensä toteuttaminen. Vaikutukset ovat kuitenkin enimmältään sopeuttavia, vallitsevaa tilannetta ja korkeintaan rauhallista kehitystä tukevia. Vapaa sivistystyö - ja aikuiskasvatus yleisemminkin - näyttäisi kadottaneen kriittisen, yhteiskunnan ja yksilön muutosta tavoittelevan roolin, joka sillä oli vielä 1800-luvun lopulla.

Artikkeli pohjautuu tutkimukseen, jossa kartoitettiin vapaan sivistystyön oppilaitoksissa vuonna 2007 opiskelleiden aikuisten kokemia koulutukseen osallistumisen aikaansaamia laajempia vaikutuksia (Manninen \& Luukannel 2008). Laajemmilla vaikutuksilla (wider benefits, Desjardins 2008) tarkoitetaan opiskelun ja koulutukseen osallistumisen tuottamia vaikutuksia, jotka eivät ole välittömiä oppimistuloksia, vaan kokonaisval taisempia seurannais- ja rinnakkaisvaikutuksia, jotka näkyvät esimerkiksi parantuneena elämänlaatuna, sosiaalisten verkostojen vahvistumisena ja henkisenä hyvinvointina. Tutkimuksessa laajempia vaikutuksia arvioitiin (1) yksilön, (2) kansalaisen ja (3) työntekijän näkökulmasta. Näkökulmien avulla aikuisopiskelun vaikutusten tarkastelua laajennettiin yksilötasolta myös yhteisöjen (perhe, työpaikka, lähiyhteisöt) ja yhteiskunnan tasolle (ns. aktiivinen kansalaisuus, koulutuksen kansanterveydelliset ja-taloudelliset vaikutukset). Tulosten avulla voidaan arvioida vapaan sivistystyön opintojen roolia ja merkitystä yksilö- ja yhteiskuntatasolla.

Artikkelin empiirisessä osassa kuvaan lyhyesti tutkimuksen päätuloksia. Ne osoittavat, että aikuisopiskelulla on välittömien oppimistulosten lisäksi myös laajempia vaikutuksia, jotka ovat merkittäviä yksilön, yhteisöjen ja yhteiskunnan kannalta. Vapaan sivistystyön oppilaitosten koulutustarjonnalla on siten merkittävä yhteiskunnallinen tehtävä, sillä se tuottaa monia koulutus- ja sosiaalipoliittisesti keskeisiä vaikutuksia, kuten esimerkiksi aktiiviseen kansalaisuuteen ja elinikäiseen oppimiseen liittyviä valmiuksia. Vaikutukset ovat merkittäviä myös työelämän kannalta, sillä opiskelu lisää suoraan työssä hyödynnettäviä valmiuksia (esimerkiksi tietotekniikan hallinta, kielitaito) ja tukee työssä jaksamista.

Artikkelin loppupuolella esitän tulosten kriittisemmän tarkastelun pohjalta huomioita siitä, kuinka vapaa sivistystyö ja ehkä aikuiskasvatus yleisemminkin näyttäisi kadottaneen kriittisen, yhteiskunnan ja yksilön muutosta tavoittelevan roolin, joka sillä oli esimerkiksi 1800-luvun lopulla. Kansansivistyshän oli alkujaan sosiaalinen liike, jonka tavoitteena oli taistelu tietämättömyyttä, alkoholismia ja sosiaalista epäoikeudenmukaisuutta vastaan ja itsenäisen kansa(laisyhteis)kunnan luominen.

Vapaan sivistystyön roolia koskeva johtopäätös pohjautuu analyysiin, jossa on hyödynnetty Burrell \& Morganin (1979), Mannisen (1998) ja Schullerin ym. (2002) koulutuksen yhteiskunnallista roolia kuvaavien tarkastelujen pohjalta kehitettyä viitekehystä.

Aikuiskasvatuksella näyttäisi nykyään olevan enemmänkin sopeuttamista, vallitsevaa tilannetta ja korkeintaan rauhallista kehitystä tukeva rooli yhteiskunnassa, vaikka esimerkiksi alan keskeinen kirjallisuus tarjoaa lähes yksinomaan yksilöllistä 
tai yhteiskunnallista muutosta tavoittelevia malleja (esimerkiksi Freire 1972; Mezirow 1981; hooks 2007).

\section{Wider benefits -lähestymistapa kasvatustieteissä}

Koulutuksen laajempia vaikutuksia tutkiva lähestymistapa (Schuller ym. 2002) pyrkii selvittämään, miten ihmiset, ryhmät, organisaatiot ja yhteiskunta hyötyvät koulutuksesta. Kyseessä ei ole koulutuksen vaikuttavuuden, vaan vaikutusten arviointi. Kun koulutuksen vaikuttavuuden arviointi lähtökohtaisesti keskittyy tavoitteiden saavuttamisen arviointiin tietyssä ryhmässä tietyllä ajallisesti rajatulla jaksolla, pyritään laajempia vaikutuksia arvioimaan tavoitevapaasti, kaikkien mahdollisten vaikutusten näkökulmasta ja usein myös viiveellä.

Artikkelissa ei tarkastella wider benefits-lähestymistavan asemaa koulutuksen evaluaation kentässä, vaan kuvataan vain yksi siitä näkökulmasta tehty arviointitutkimus. Lähestymistapa avaa kuitenkin uusia mahdollisuuksia ja tarkastelukulmia koulutuksen arviointiin, ja tätä varsin vähän käytettyä näkökulmaa tulisi hyödyntää laajemminkin.

Lähestymistapaa on soveltanut erityisesti Lontoon yliopiston tutkimusyksikkö (University of London, Centre for Research on the Wider Benefits of Learning, www.learningbenefits.net), jossa erilaisten toisiaan tukevien aineistojen ja tutkimusasetelmien avulla on tutkittu koulutustason ja koulutukseen osallistumisen moninaisia vaikutuksia (esimerkiksi Feinstein, Hammond, Woods, Preston, \& Bynner 2003; Schuller, Hammond, BrassettGrundy, Green, Hammond \& Preston 2002).

Aikaisempien tutkimusten mukaan (Feinstein ym. 2003; Schuller ym. 2002; Desjardins \& Schuller 2007; Manninen \& Luukannel 2008, 20-22) aikuiskoulutuksella on vaikutusta esimerkiksi käyttäytymis- ja asennemuutoksiin, terveyskäyttäytymiseen (tupakointi, alkoholin käyttö), sosiaalisiin verkostoihin ja henkiseen hyvinvointiin. Aikuisopiskelu myös lisää kommunikaatiotaitoja, sosiaalisia taitoja, kansalaisuuteen liittyviä asenteita ja opiskeluvalmiuksia. Myös ryhmään kuulumisen tunne lisääntyy ja minäkuva kehittyy.

Koulutus kehittää myös sosiaalista pääomaa ja sosiaalista koheesiota, sillä koulutukseen osallistuminen lisää tiettyjä metakompetensseja, kuten aktiivisen kansalaisuuden merkityksen tiedostamista ja siinä tarvittavien konkreettisten taitojen kehittymistä (Schuller ym. 2002). Koulutukseen osallistuminen myös mahdollistaa sosiaalisten verkostojen kehittämisen ja ylläpidon, mikä puolestaan on yksi sosiaalisen pääoman (Putnam 1995) perusta.

\section{AINEISTO}

Tutkimus kohdentui vapaan sivistystyön oppilaitoksiin, joissa opiskelu on omaehtoista ja usein harrastustavoitteista. Vapaan sivistystyön oppilaitosten (kansalaisopistot, kansanopistot, kesäyliopistot, opintokeskukset ja liikunnan oppilaitokset) opintoihin osallistui vuonna 2005 yhteensä 1.066.932 opiskelijaa (Kumpulainen 2007). Vuonna 2008 valtio tuki opintoja 192 miljoonalla eurolla.

Aineisto pohjautuu vuonna 2007 vapaan sivistystyön opintoihin osallistuneiden aikuisten kokemuksiin opiskelun laajemmista vaikutuksista. Tutkimukseen osallistui yhteensä yli 1800 aikuisopiskelijaa eri aineistonhankintakierroksilla. Aineiston hankinnassa hyödynnettiin aineistotriangulaatiota (Denzin \& Lincoln 1994). Yksilökohtaisten teemahaastatteluiden ( $\mathrm{n}=19$ aikuisopiskelijaa) ja ryhmähaastatteluiden (12 opintoryhmää, joissa yhteensä 77 aikuisopiskelijaa) lisäksi toteutettiin verkkokysely ( $\mathrm{n}=1744$ aikuisopiskelijaa).

Suurin osa tutkimuksen verkkokyselyyn osallistuneista (66\%) oli kansalais- ja työväenopistojen opiskelijoita. Myös perusjoukosta suurin osa (57\%) on kansalais- ja työväenopistojen opiskelijoita. Opintokeskuksissa vastaajista oli opiskellut 14 ja kesäyliopistoissa 12 prosenttia. Vastaajista - kuten opiskelijoistakin - enemmistö (76\%) oli naisia, ja puolet vastaajista oli kokopäivätyössä. Eläkeläisiä oli 29 prosenttia vastaajista. Yli kolmasosa vastaajista (37\%) kuului 50-63-vuotiaiden ikäryhmään. Profiililtaan vastaajajoukko vastaa siten vapaan sivistystyön opintoihin osallistuneiden perusjoukkoa (Kumpulainen 2007) varsin hyvin.

Kyselylomakkeessa oli sekä suljettuja että avoimia kysymyksiä. Kyselyn päämittarin muodosti lista mahdollisista opiskelun tuottamista vaikutuksista, joiden toteutumista omalla kohdallaan vastaajia pyydettiin arvioimaan. Lista muodostettiin yksilö- ja ryhmähaastattelujen tulosten ja joidenkin aikaisempien tutkimusten tulosten pohjalta.

Laadullisen aineiston eli haastatteluiden ja kyselylomakkeen avointen vastausten analyysissa käytettiin laadullista sisällönanalyysia, jonka avulla paikannettiin tekstistä opiskelun ja osallistumisen tuottamia vaikutuksia aineistolähtöisesti. Kysely- 
lomakkeen strukturoitujen kysymysten analyysi toteutettiin tilastollisin menetelmin (katso Manninen \& Luukannel 2008, 32).

\section{Laadullinen aineisto ja sen analyysi}

Laadullisten tulosten ominaispiirre tässä tutkimuksessa on se, että ne kuvaavat aikuisopiskelijoiden spontaaneja, itse ilmituotuja koulutuksen vaikutuksia, kun taas lomakekyselyn valmiiden vastausvaihtoehtojen tuottamassa kokonaiskuvassa on kyse siitä, kuinka moni tunnistaa kyseisiä vaikutuksia omalla kohdallaan, kun niitä tarjotaan valmiina listana vastaajille.

Artikkelissa kuvataan tarkemmin kyselylomakkeen avointen vastausten analyysin tulokset. Laaja ( $n=1744$ vastaajaa, avoimia kysymyksiä neljä kappaletta) aineisto tarjoaa empiirisesti vahvan, edustavan ja tulosten osalta siirrettävän (transferable; Lincoln \& Guba 1985) tuloksen.

\section{Yksilö- ja ryhmähaastattelut}

Tutkimus käynnistyi yksilö- ja ryhmähaastatteluilla, joiden avulla tuotettiin laadullista esiymmärrystä tutkittavasta ilmiöstä kyselylomakkeen suunnittelun pohjaksi. Teemahaastatteluihin $(\mathrm{n}=19)$ poimittiin erilaisista vapaan sivistystyön oppilaitoksista kohderyhmään kuuluvia aikuisopiskelijoita. Teemahaastatteluiden tulosten analyysin tukena on käytetty myös haastatteluissa käytettyä jaottelua, jossa vastaajia pyydettiin erittelemään opiskelun laajempia vaikutuksia työelämän, yksilönä kehittymisen ja aktiivisen kansalaisuuden näkökulmasta. Alla on kuvattu esimerkkinä erään espanjan kieltä opiskelleen 32 vuotiaan naisen vastauksia. Vastauksissa esiintyvät vaikutuksia kuvaavat lausumat on tummennettu.

Lausumista alkaa hahmottua erilaisia teemoja, kuten kielitaidon kehittyminen, opiskelun ilo, itsetunnon ja opiskelijaminäkuvan vahvistuminen ja itsensä kehittämisen halu.

Taulukko 1. Esimerkki yksilöhaastattelusta

\begin{tabular}{|c|c|c|}
\hline & Mitä hyötyä opiskelusta on ollut? & $\begin{array}{l}\text { Mitä laajempia vaikutuksia } \\
\text { opiskelulla on ollut? }\end{array}$ \\
\hline $\begin{array}{l}\text { Työelämään liittyen? } \\
\text { Työhön ja ammattiin } \\
\text { liittyvät vaikutukset }\end{array}$ & $\begin{array}{l}\text { Ei suoraan, mutta espanja on ainoa } \\
\text { romaaninen kieli, jota olen opis- } \\
\text { kellut; Nyt pystyy ymmärtämään } \\
\text { jotain ranskasta ja italiasta. } \\
\text { Joskus tulee vastaan dokumentteja, } \\
\text { joilla kielitaidosta on ollut } \\
\text { välillistä hyötyä työhön. }\end{array}$ & $\begin{array}{l}\text { Laajempi vaikutus on se, että on } \\
\text { tietoa romaanisista kielistä. Edel- } \\
\text { lisessä työpaikassa tuli vastaan } \\
\text { papereita ranskaa tms, joita } \\
\text { pystyin osittain ymmärtämään. }\end{array}$ \\
\hline $\begin{array}{l}\text { Yksilönä? } \\
\text { Ihmisenä ja yksilönä } \\
\text { kasvaminen ja } \\
\text { kehittyminen }\end{array}$ & $\begin{array}{l}\text { On ollut hyötyä, osaa keskustella } \\
\text { espanjaksi. Olen käynyt Espanjas- } \\
\text { sa ja Venezuelassa, kielitaidosta } \\
\text { oli hyötyä. Kielitaidon } \\
\text { kehittäminen on tärkeää ja } \\
\text { mukavaa. }\end{array}$ & $\begin{array}{l}\text { Laajempi vaikutus on se, että on } \\
\text { tietoa romaanisista kielistä, se on } \\
\text { hyödyllistä. Ymmärtää paremmin } \\
\text { on espanjan ja vaikka portugalin } \\
\text { tekstejä. Kun nyt oli muutaman } \\
\text { vuoden tauko opiskelussa, niin on } \\
\text { hyvä huomata, että kykenee vielä } \\
\text { opiskelemaan kieliä. Ja tietynlai- } \\
\text { nen tuntu siitä, että kehittää itse- } \\
\text { ään tuollakin alalla. }\end{array}$ \\
\hline $\begin{array}{l}\text { Kansalaisena? } \\
\text { Yhteisöön ja yhteis- } \\
\text { kuntaan osallistumi- } \\
\text { sen erilaisiin roolei- } \\
\text { hin liittyvät } \\
\text { vaikutukset. }\end{array}$ & $\begin{array}{l}\text { Olin aikaisemmin työssä kansalais- } \\
\text { järjestössä, niin siellä kielitaito oli } \\
\text { enemmän työhön liittyvää, aktiivi- } \\
\text { seen kansalaisuuteen liittyvää. Nyt } \\
\text { ei ole ihan suoraa käyttöä espan- } \\
\text { jalle. }\end{array}$ & \\
\hline
\end{tabular}


Vastaavalla tavalla poimittiin ryhmähaastatteluista vaikutuksiin liittyviä lausumia. Seuraavassa aineistoesimerkissä kuvataan sukututkimuskurssin opintoryhmän ryhmähaastattelun otetta, jossa puhutaan opiskelun yksilötason vaikutuksista. Esille nousevat lausumat on tummennettu.

Mies 1: Tämä sukututkimuksen kurssi on konkreettinen siinä mielessä, että sukututkimusta on vaikea tehdä, jos ei osaa käyttää siinä tietokonetta. Näillä aikuiskasvatusopiston kursseilla on oppinut sen tekniikan. Omaan sukutarinaan voi sitten syventyä. Minun on pitänyt kouluttautua itseni tukihenkilöksi.

Mies 2: Atk on tässä valtavan tärkeää. Ne on pitänyt kaikki oppia kantapään kautta. Huomaa sellaisen asian, että jos ei sitä viikottain tee, niin kuukauden kuluttua ei muista enää kyseistä asiaa. Sen pitäisi tulla rutiiniksi. Kurssilla oli opetusta, miten netistä haetaan arkistotietoa. Muutakin tietoa opeteltiin hakemaan.

Nainen 1: Mä olen saanut paljon hyötyä siitä, että opin lukemaan kirkonkirjoja, löydän arkistosta tietoja. On mielenkiintoista lukea niitä mikrokortteja. Mulle tietokone töissä on niin tavallinen väline. Mä olen niin alussa vielä sukututkimuksessa, ja olen saanut ahaa-elämyksiä arkistossa.

Mies 1: Siinä vaiheessa jos haluaa kuvia, niin silloin tarvitsee välttämättä tietokonetta.

Mies 4: Kouluttajamme sanoi, että todellinen tieto löytyy arkistoista, joku on ne sieltä siirtänyt nettiin. Siinä voi tulla virheitä. Mitä alkuperäsempään paperiin pääsee käsiksi, sitä parempi ja sitä oikeampaa tietoa. Virheitä sielläkin on.

Lyhyestä ryhmäkeskustelun pätkästä nousee esille jo paljon lausumia, jotka liittyvät laajempiin teemoihin atk-taidot, tiedonhakutaidot, oppimisen ilo ("ahaa-elämyksiä") ja harrastukseen liittyvä yleissivistys ("todellinen tieto löytyy arkistoista").

\section{Avoimet vastaukset}

Lomakkeen avoimet kysymykset olivat samat kuin yksilö- ja ryhmähaastatteluissa käytetyt haastatteluteemat. Ne muodostivat jatkumon, jossa vastaajia pyydettiin arvioimaan opiskelun myötä tapahtunutta oppimista, sen tuottamaa hyötyä, laajempia vaikutuksia ja muita vaikutuksia.
Avointen vastausten laajuus vaihteli muutamista "ei mitään" -tyyppisistä ja varsin tiiviistä vastauksista alla kuvattuihin laajempiin vastauksiin, joita aineistosta on suurin osa. Avoimista vastauksista oli siten mahdollista paikantaa suhteellisen helposti ja luotettavasti tiettyjen pääteemojen alle sijoittuvia lausumia. Esimerkiksi seuraavista esimerkeistä löytyy monenlaisia opiskelun vaikutuksia:

On ollut hauska huomata, että vielä oppii uutta. Olen kesän aikana käynyt Virossa kielen jatkokurssilla. Suunnittelen rohkeammin vaatteita, koska kurssilla valmistamani työt ovat kelvanneet näyttelyihin. (\#21, s. 1947 toimistosihteeri, nainen, kansalaisopisto)

Työssä jaksamiseen omalla harrastuksella on erittäin suuri positivinen vaikutus. Laulaessa keho ja mieli elpyy, sitä voisi verrata sisäiseen voiteluun tai aromaattiseen kylpyyn. Jokainen laulutunti tuo positiivista virettä roimasti. (\#123, s. 1948, lehtori, nainen, opintokeskus)

On syntynyt uusia elämänalueita ja elämä on tullut monipuolisemmaksi (\#1422, s. 1951, asianajaja, mies, kansalaisopisto)

Tiedot ja taidot englannin kielestä ovat karttuneet erittäin paljon. Oletan tämän myös auttavan etenemistä uralla eteenpäin. Hyvä opetus ja edistyminen opinnoissa ovat innostaneet jatkamaan opintoja muillakin aiheilla. (\#1081, s. 1975, insinööri, mies, kansalaisopisto)

Avoimet vastaukset purettiin lausumiksi ja teemoiteltiin laadullisen sisällönanalyysin avulla pääteemojen alle. Esimerkiksi alla on purettu yhden vastaajan vastaus kysymykseen "mitä hyötyä näiden asioiden oppimisesta on ollut" eri pääteemojen alle sijoittuviin lausumiin.

\section{AIKUISOPISKELUN LAAJEMMAT VAIKUTUKSET}

\section{Vaikutusten mallinnus}

Tutkimuksen päätulos on, että vapaan sivistystyön opintoihin osallistumisella on selviä ja laajoja vaikutuksia aikuisten elämässä. Vaikutukset liittyvät oppimiseen ja osaamiseen sekä opiskelun ja oppimisen tuottamiin välittömiin hyötyihin, opis- 
Taulukko 2. Esimerkki avointen vastausten analyysista

\begin{tabular}{|c|c|c|}
\hline Vastaus & Lausuma & Pääteemat \\
\hline \multirow{4}{*}{$\begin{array}{l}\text { Kaikki on ollut sivistävää, } \\
\text { hauskaa, virkistävää } \\
\text { ja innostavaa. } \\
\text { Kieliopinnoista on } \\
\text { hyötyä myös matkustelussa, } \\
\text { on mukava kommunikoida } \\
\text { alkuasukkaiden kanssa. }\end{array}$} & Kaikki on ollut sivistävää & Yleissivistys \\
\hline & , hauskaa & Oppimisen ilo \\
\hline & , virittävää ja innostavaa. & Uusia virikkeitä \\
\hline & $\begin{array}{l}\text { Kieliopinnoista on hyötyä } \\
\text { myös matkustellessa, on } \\
\text { mukava kommunikoida alku- } \\
\text { asukkaiden kanssa. }\end{array}$ & $\begin{array}{l}\text { Kv- } \\
\text { kulttuuriosaaminen }\end{array}$ \\
\hline
\end{tabular}

kelun rinnakkaisvaikutuksiin ja seurannaisvaikutuksiin. Alla kuvataan päätulokset vain laadullisen aineiston osalta. Tarkempi kuvaus analyyseista ja tilastolliseen aineistoon pohjautuvista tuloksista löytyy alkuperäisestä raportista (Manninen \& Luukannel 2008).

Verkkokyselyn avoimissa kysymyksissä pyydettiin vastaajia arvioimaan opiskelun aikaansaamien hyötyjen lisäksi opiskelun (1) laajempia vaikutuksia ja (2) muita vaikutuksia. Kysymyssarjan tavoitteena oli kartoittaa laajasti opiskelun aikaansaamia vaikutuksia, erityisesti mahdollisia opiskelusta syntyviä seurannais- ja rinnakkaisvaikutuksia, kuten henkiseen hyvinvointiin ja elämäntilanteeseen liittyviä vaikutuksia.

Kaikki avoimet kysymykset analysoitiin samalla periaatteella aineistolähtöisesti, eli pääteemat nostettiin esille kunkin kysymyksen vastauksista. Pääteemat teemoiteltiin edelleen yläteemojen alle. Esimerkiksi yläteema "Oppiminen ja osaaminen" sisältää osaamisen lisääntymiseen ja oppimistuloksiin liittyviä pääteemoja kuten "tekeminen ja osaaminen", "kv-kulttuuriosaaminen" ja "atk-osaaminen". Muita yläteemoja ovat koulutukseen osallistumisen aikaansaamat "Välittömät hyödyt", opiskeluryhmään kuulumisesta ja siellä tapahtuvasta sosiaalisesta vuorovaikutuksesta syntyvät "Opiskeluprosessiin liittyvät hyödyt", opiskelusta ja oppimisesta syntyvät "Rinnakkaisvaikutukset" sekä "Seurannaisvaikutukset". Rinnakkaisvaikutuksilla tarkoitetaan koulutukseen osallistumisen vaikutuksia, joita ei ole varsinaisesti asetettu koulutuksen tavoitteeksi, mutta joita kuitenkin syntyy osallistumisen ansiosta (esimerkiksi itseluottamuksen vahvistuminen, ystäväpiirin laajentuminen). Seurannaisvaikutuksien ilmenemiselle puo- lestaan ominaista on ajallinen viive, eli esimerkiksi henkisen hyvinvoinnin lisääntyminen näkyy yleensä vasta jonkin ajan kuluttua koulutuksen alkamisesta.

Kolme yleisintä pääteemaa liittyvät kaikki osaamisen, tietojen ja taitojen lisääntymiseen. Puolet vapaan sivistystyön tuottamista välittömistä vaikutuksista ovat erilaisten tietojen ja taitojen oppimiseen liittyviä asioita, oli kyse sitten tietotekniikan, kielten, muiden kulttuurien, käsillä tekemisen, musiikin, yhteiskuntatiedon tai kirjoittamisen hallinnasta. Toinen puoli aikuisopiskelijoiden kokemista vaikutuksista on hyvin moninaisia "pehmeämpiä” ja välillisiä elämänlaatuun liittyviä vaikutuksia, kuten oppimisen ilo, itseluottamus, elämänsisältö ja työssä jaksaminen.

Tulokset voi kuvata mallin muodossa (kuvio 1). Vapaan sivistystyön opintoihin osallistuva aikuisopiskelija saa jo opiskelutilanteessa välittömän hyödyn (itsensä toteuttamisen mahdollisuus, tunne yhteisöön kuulumisesta ja sosiaalisen vuorovaikutuksen mahdollisuus). Opiskelulla on myös välittömiä oppimiseen ja osaamisen lisääntymiseen liittyviä vaikutuksia (esimerkiksi atk-taitojen lisääntyminen). Oppimisesta on välittömiä hyötyjä (vaikkapa ajan tasalla pysyminen) ja rinnakkaisvaikutuksia (itseluottamus lisääntyy), ja kaikella tällä jonkinlaisia seurannaisvaikutuksia, esimerkiksi parantuneen henkisen hyvinvoinnin tai elämänlaadun muodossa. On syytä muistaa, että vaikutukset ovat hyvin yksilöllisiä ja eriytyvät aikuisopiskelijan henkilökohtaisen tilanteen, opiskelumotiivien ja taustan mukaan. Esimerkiksi työttömälle tai yksinäiselle eläkeläiselle yhteisöön kuulumisen tunne ja sosiaalisen vuorovaikutuksen mahdollisuus voi olla merkittävä osallistumissyy 
Kuvio 1. Vapaan sivistystyön opintojen vaikutukset

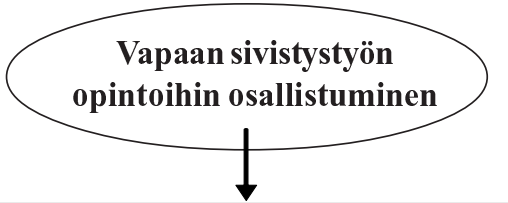

\section{OPISKELUPROSESSIIN LIITTYVÄT HYÖDYT}

Yhteisöön kuuluminen, sosiaalinen vuorovaikutus, itsensä toteuttaminen ja tekemisen ilo

VÄLITTÖMÄTHYÖDYT

Käytännön hyöty

Oppimisen ilo

Matkailu ja

vieraat kulttuurit

Jatko-opinnot

Ajan tasalla pysyminen

Välineellinen hyöty

Uusia virikkeitä

Ajattelutapa \&

asennemuutos

Uudet verkostot

\section{OPPIMINEN JA}

OSAAMINEN

Tekeminen ja osaaminen

Kv-kulttuuriosaaminen

Atk-osaaminen

Näkemysten laajentuminen

Yleissivistys

Itseilmaisutaidot ja luovuus

Tiedonhakutaidot
RINNAKKAISVAIKUTUKSET

Itsevarmuus, itsetunto, itseluottamus

Elämänpiirin laajentuminen

Ystävä- ja tuttavapiiri

Opiskeluhalukkuus

Luottamus omaan osaamiseen Mielihyvä

Oppimiskyvyn paraneminen

Osaamisen jakaminen

Muiden innostaminen opiskeluun

\section{SEURANNAISVAIKUTUKSET}

Henkinen hyvinvointi, fyysinen hyvinvointi, elämänsisältö ja -laatu, työssä jaksaminen, arjessa jaksaminen, yhteis-

kunnallinen osallistuminen

ja hyöty, kun taas kiireistä työtä ihmisten parissa tekevälle esimerkiksi itsensä toteuttaminen voi olla luontevampi tavoite.

Itsensä toteuttaminen ja ryhmän merkitys tulee hyvin esille 52-vuotiaan naisen yksilöhaastattelussa:

Olen nuorena pyrkinyt 2 kertaa Ateneumin taidekouluun, jonne en päässy. Pääsin yliopistoon. Nyt tavallaan toteutan sitä nuoruuden unelmaa. Tässä käsillä tekemisessä saa paljon onnistumisen kokemuksia. Kursseilla annetaan töistä kritiikkiä. Opettaja arvioi töitä ja neuvoo. Kritiikin sieto on kasvanut. Siinä kasvaa ihmisenäkin. Ryhmä kritikoi toisiaan epävirallisesti. Ryhmä on tärkeä.

Avoimista vastauksista nousevat teemat tulevat hyvin esille myös seuraavan keramiikkakurssille osallistuneen 37-vuotiaan naisen haastatteluvastauksessa:

Löytää sisältään pienen keraamikon. Tässä taideharrastuksessa pystyn toteuttamaan itseäni menestyksekkäästi.. Se on tyydyttävä harrastus. Ihan löytää itsestään sellaisia taitoja ja kykyjä pystyä tekemään keramiikasta hienoja töitä. Luovuuden löytäminen, ideoiden toteuttaminen haluamallaan tavalla.

Sama henkilö kuvaa opiskelun laajempia vaikutuksia seuraavasti:

Elämässä ja arjessa on hyötynä ja ilona nämä toteuttamisen teemat. Voi rakentaa haluami- 
aan tarve-esineitä, joita ei kaupasta saa. Ja edullisesti. Taideliikkeiden keramiikkahinnat on korkeita. Tuntuu, että ite pystyy tekemään parempaa ja hienompaa omien ideoiden pohjalta. Ja lahjan saaja arvostaa omatekoista. (nainen $37 \mathrm{v}$.)

Mallissa nuolilla kuvatut "kausaalisuhteet" voidaan hyvin perustella aineistoesimerkeillä. Esimerkiksi opiskeluryhmän merkitys, taitojen lisääntymisen rooli ja aktiivisen kansalaisuuden lisääntyminen näiden kautta tulee hyvin esille seuraavasta lainauksesta:

Kun aloitin lausuntapiirissä, olin hiljattain muuttanut uutena asukkaana kuntaan. Ryhmän hyvä vastaanotto loi pohjaa muiden sosiaalisten kontaktien syntymiselle kunnassa. Esiintymistaitojen ja kontaktien karttuminen on vienyt minua myös muiden yhdistysten toimintaan mukaan. (\#439, s. 1967, kulttuurituottaja, nainen, kansalaisopisto)

Muita rinnakkais- ja seurannaisvaikutuksia kuvaavat seuraavat lainaukset:

Samanhenkisten ja samaan pyrkivien kanssaihmisten yhteiset pyrkimykset vaikuttavat sekä ruumiilliseen että henkiseen hyvinvointiin. Pystyn kotona hyödyntämään kurssilla opittuja taitoja. (\#471, s. 1943 eläkeläinen nainen, kansalaisopisto)

Tietokoneen käytössä tiedot ja taito on karttunut. Yleissivistystä on tullut lisää sekä itsetunto ja itseluottamus omaan tietokoneen käyttöön on vahvistunut. (\#485, s. 1957, perushoitaja, nainen, kansalaisopisto)

Nousu sängyn pohjalta aktiiviseksi luovaksi ihmiseksi. Olen jopa saanut muotokuvatilauksia. (\#559, s. 1945, pankkitoimihenkilö, nainen, kansalaisopisto)

Schullerin ym. (2002, 6) mukaan tutkimuskirjallisuudessa on vain vähän esimerkkejä siitä, että koulutus lisäisi fyysistä hyvinvointia. Ainoa poikkeus olivat ikääntyneet, joiden kohdalla löytyy yhteyksiä koulutukseen osallistumisen ja fyysisen terveyden välille. Henkisen hyvinvoinnin osalta vaikutukset ovat kuitenkin selviä, kuten kävi ilmi myös tässä tutkimuksessa. Voidaan siis hyvin väittää, että aikuiskoulutusjärjestelmällä on yhteiskunnassa myös merkittävä kansanterveydellinen rooli. Tässä tutkimuksessa 28 prosenttia vastaa- jista toi itse esille henkisen hyvinvoinnin lisääntymisen, ja 13 prosenttia koki myös fyysisen terveydentilan kohentuneen vapaan sivistystyön opintojen myötä. Strukturoitujen kysymysten tilastoanalyysissa 62 prosenttia vastaajista koki, että opiskelu on ainakin jonkin verran auttanut ylläpitämään fyysistä kuntoa. Henkisen hyvinvoinnin parantumisen ainakin jonkin verran tunnisti jopa 95 prosenttia vastaajista.

\section{Vapaa sivistystyö tuottaa "kaikkea hyvää ja aktiivisia kansalaisia"}

Tutkimuksen tulokset ovat linjassa aikaisempien tutkimusten tuloksien kanssa (Hammond 2002; Schuller ym. 2002; Dehrman \& Stacey 1997; Feinstein ym. 2003; vapaan sivistystyön osalta katso Riihimäki \& Saarenpää-Numminen 2005; Kansalaisopistotoiminnan vaikuttavuus 2001). Voidaan siten olettaa, että vapaan sivistystyön opinnoilla ja aikuisopiskelulla yleensä on laajempia vaikutuksia ihmisten elämässä. Näillä vaikutuksilla on myös - ainakin viiveellä - yhteisöllistä ja yhteiskunnallista merkitystä, jota ei kuitenkaan välttämättä tunnisteta riittävästi.

Omaehtoisella aikuisopiskelulla näyttäisi olevan suuri koulutus- ja yhteiskuntapoliittinen merkitys. Kuten taulukko 3 kuvaa, tukevat opiskelun laajemmat vaikutukset hyvin useiden yhteiskunnallisten haasteiden kohtaamista. Osa näistä haasteista on maailmanlaajuisia megatrendejä kuten globalisaatio, osa EU:n poliittisia tavoitteita (Elinikäinen Oppiminen, Aktiivinen kansalaisuus), osa sosiologisia ilmiöitä (esimerkiksi sosiaalinen pääoma).

Sosiaalinen pääoma (Bourdieu 1986; Putnam 1995) on ollut laajasti esillä koulutuksen laajempia vaikutuksia käsittelevässä kirjallisuudessa. Esimerkiksi Schuller ym. (2002) analysoivat tuloksiaan sosiaalisen ja inhimillisen pääoman sekä sosiaalisen koheesion käsitteiden avulla. Kotimaisessa kirjallisuudessa sosiaalinen pääoma on yhdistetty esimerkiksi terveyden (Hyyppä 2004) ja työorganisaatioiden (Koivumäki 2008) tarkasteluun. Koulutuksen yhteydessä yleisemmin käytetyn inhimillisen pääoman (human capital) lisäksi on puhuttu kulttuuripääomasta ja älyllisestä pääomasta (intellectual capital).

Koska sosiaalinen pääoma perustuu (Putnamin 1995 mukaan) sosiaalisiin verkostoihin, luottamukseen, normeihin ja yhteistyöhön, se ei ole yksilön ominaisuus vaan sosiaalinen, ihmisryhmien toimin- 
Taulukko 3. Yhteiskunnalliset haasteet ja aikuisopiskelun laajemmat vaikutukset

\begin{tabular}{|c|c|}
\hline Haasteita & Mitä aikuisopiskelu tarjoaa? \\
\hline Globalisaatio & Kielitaito, kulttuurien tuntemus \\
\hline Aktiivinen kansalaisuus & Yhteisöön kuuluminen, yhteiskunnallinen osallistuminen \\
\hline Sosiaalinen pääoma & Verkostot, itseluottamus \\
\hline Elinikäinen oppiminen & $\begin{array}{l}\text { Opiskelumotivaatio, luottamus omiin kykyihin, oppimisen } \\
\text { ilo, opiskeluvalmiudet }\end{array}$ \\
\hline Työllistettävyys & Käytännön taidot, atk-taidot, yleissivistys, työssä jaksaminen \\
\hline Terveys & Fyysinen hyvinvointi \\
\hline Henkinen hyvinvointi & $\begin{array}{l}\text { Henkinen hyvinvointi, työssä ja arjessa jaksaminen, } \\
\text { elämisen laatu }\end{array}$ \\
\hline
\end{tabular}

taan liittyvä ilmiö. Tätä kautta myös koulutukseen osallistumisen yksilöllisten vaikutusten tarkastelu laajenee yhteisöllisten merkitysten tarkasteluksi. Sosiaalisten verkostojen syntyminen ja vahvistuminen oli yksi tässä tutkimuksessa havaittu koulutukseen osallistumisen vaikutus. Myös Schullerin ym. (2002) tutkimuksessa sosiaalisten verkostojen vahvistuminen oli yksi koulutuksen vaikutuksista (liittyminen uusiin verkostoihin, olemassa olevien verkostojen laajentuminen tai vanhojen verkostojen uudelleen syntyminen).

Sosiaalisella pääomalla ja yhteisön yhteenkuuluvuutta lisäävällä sosiaalisella koheesiolla on liittymäkohta aktiiviseen kansalaisuuteen, jos se määritellään perinteiseen tapaan (esim. Honohan 2005) lähiyhteisöihin osallistumisena. Aktiivinen kansalaisuus vaatii verkostoitumista ja tiettyjä taitoja, joita aikuiskoulutukseen osallistuminen puolestaan vahvistaa. Tässä tutkimuksessa tällaisia olivat esimerkiksi itseluottamus ja tunne yhteisöön kuulumisesta, jotka tekevät yhteiskunnallisen osallistumisen ja vaikuttamisen helpommaksi. Schullerin ym. (2002) tutkimuksessa näitä valmiuksia nimitettiin metakompetensseiksi ("metacompetences"), ja perustaidoiksi ("generic skills", "basic competences") joita jokaisella kansalaisella tulisi olla, jotta he täyttäisivät "kansalaisuuden perusvaatimukset" (Schuller ym. 2002, 7).

\section{TRANSFORMATIIVISTA VAI SOPEUTTAVAAAIKUISKASVATUSTA?}

Tulosten kriittisempi tarkastelu antaa viitteitä siitä, että vapaan sivistystyön tuottamat laajemmat vaikutukset painottuvat lähes yksinomaan yksilölliseen selviytymiseen ja sopeutumiseen erilaisissa elämäntilanteissa. Kuten artikkelissa aiemmin esitetyt aineistoesimerkit osoittavat, tuottaa opiskelu pääasiassa mielihyvää, jaksamista ja hyvinvointia esimerkiksi työttömyystilanteissa, raskaan työn vastapainoksi tai eläkkeelle siirtymisen yhteydessä. Aineistosta ei sen sijaan löydy "kriittiseen tiedostamiseen" (Mezirow) saati "alistettujen kapinaan" (Freire) viittaavia lausumia. Myös yhteisöllisen toiminnan syntymistä kuvaavat lausumat loistavat poissaolollaan, vaikka vastaajia pyydettiin yksilötason vaikutusten lisäksi arvioimaan myös työhön ja kansalaisuuteen liittyviä vaikutuksia.

Radikaalimpaa muutosta kuvaavien lausumien puuttuminen saattaa olla tietysti myös jonkinlainen metodologinen ongelma, vaikkakaan sellaista selitystä ei ole vielä löytynyt. Kolme erilaista aineistotyyppiä (yksilö- ja ryhmähaastattelut sekä avoimet vastaukset lomakkeella) tuottivat myös identtiset tulokset, ja ilmiön systemaattisuus eli vastausten toistuva tyyppi viittaisi myös siihen, ettei suurempia muutoskokemuksia opiskelun kautta synny.

Opintoihin osallistumisella näyttäisi siten olevan eräänlainen sopeuttava rooli, jopa sosiaalisen kontrollin ja sosiaalisen kudoksen (fabric; Schuller ym. 2002) vahvistaminen.

Tulkinnan tueksi esitetään alla viitekehys, joka pohjautuu Burrellin \& Morganin (1979; katso myös Paulston 1996) nelikenttään, jossa vertailtiin yhteiskuntaa ja organisaatioita koskevia teorioita kahden ulottuvuuden (radikaali muutos vs. rau- 
hallinen kehitys sekä yksilö vs. yhteiskunta) avulla. Mallia on sovellettu työllistymistä edistävän koulutuksen koulutuspoliittisten linjausten ja didaktisten lähestymistapojen analyysissa (Manninen 1998). Esimerkiksi kriittinen humanismi ja transformatiivinen oppiminen (Mezirow 1981; 1990) sijoittuu nelikentässä radikaalin humanismin alueelle, jossa tavoitteena on yksilötason muutos. Malcolm Knowlesin $(1984,1985)$ andragogiikka puolestaan on humanistinen malli, joka tukee pääsiassa yksilöllistä selviytymistä ja sopeutumista, koska siitä puuttuvat kriittiset mekanismit, joilla voisi haastaa yksilön valintoja ja yhteiskunnallista nykytilaa (Manninen, Kontiainen \& Kauppi 1989).

Myös Schuller ym. $(2002,12)$ käyttivät vastaavaa jaottelua jakaessaan koulutuksen laajempia vaikutuksia transformatiivisiin ja ja säilyttäviin(sustaining). Näitä eri viitekehyksiä yhdistelevä malli on esitetty kuviossa 2.

Aikuiskasvatuksen suuret nimet kuten Eduard Lindeman (1926), Paolo Freire (1972) ja Yrjö Engeström (1994) sijoittuvat nelikentässä radikaalin funktionalismin alueelle, koska niissä on tavoitteena merkittävä muutos yhteiskunnan (Lindeman, Freire) tai organisaation tasolla (Engeström). Aikuiskoulutuksen perinteisemmät mallit sen sijaan löytyvät kuvion funktionalismia edustavasta oi- keasta alakulmasta. Ne pohjautuvat vahvasti Taylorismiin ja sen seuraajiin (Taylor 1911; Tyler 1949; Gagne 1987; Suomessa Ekola \& Vaherva 1987, Peltonen 1985). Tavoitteena näissä lähestymistavoissa on koulutuksella sopeuttaa työvoima työtehtäviin tarkalla opettajajohtoisella koulutuksella, ja niiden rooli on siten olemassa olevia käytäntöjä uusintava ja vahvistava.

Vapaan sivistystystyön vaikutukset ovat selvästi yksilön sopeutumista ja selviämistä tukevia. Tällaisia vaikutuksia ovat esimerkiksi itsensä toteuttaminen, mielihyvä, oppimisen ilo ja henkinen hyvinvointi. Muille nelikentän alueille on sijoitettavissa vain yksittäisiä vaikutuksia. Yhteisöjä vahvistavia vaikutuksia ovat esimerkiksi uudet verkostot, yhteisöön kuulumisen tunne ja uudet ystävät. Muutosta tuottavalle alueelle on sijoitettavissa korkeintaan uudet ideat ja asennemuutos (yksilön muutos) sekä yhteisön muutoksen alueelle pieninä "ituina" ehkäpä osaamisen jakaminen ja muiden innostaminen opiskeluun. Muutoksen ehtona on kuitenkin esimerkiksi asennemuutokseen liittyvä kriittinen tiedostaminen (vrt. Mezirow), jota aineistosta ei ole paikannettavissa.

Sopeutumista ei pidä nähdä yksinomaan haitallisena ilmiönä, sillä esimerkiksi muuttuneeseen työmarkkinatilanteeseen tai teknologian kehityk-

Kuvio 2. Aikuiskasvatuksen lähestymistapojen vertailumalli (soveltaen Burrell \& Morgan 1979, Manninen 1998 ja Schuller ym. 2002).

\section{TAVOITTEENA MUUTOS (Muutosta tukeva oppiminen)}

Yksilön muutos

* tiedostaminen, yksilötason muutos

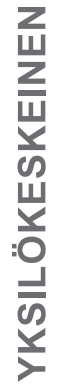

* transformatiivinen

oppiminen (Mezirow)
Yhteisö- tai organisaatiotason muutos

* organisaation kehittäminen

* ekspansiivinen oppiminen

(Engeström)

* yhteisökasvatus (Lindeman;

Freire, bell hooks)

Työyhteisöön ja yhteiskuntaan sopeuttava koulutus

* työelämän ja yhteiskunnan tarpeista lähtevä koulutus

* koulutusoppaat (Tyler; Ekola \& Vaherva) 
seen sopeutuminen oppimisen kautta on usein yksilön, organisaation ja yhteiskunnan selviytymisen perusehto. Sopeuttava koulutus kuitenkin mahdollistaa "valtaapitävien" ohjailevan roolin tai ainakin sulkee pois mahdollisuuden tuottaa koulutuksella jotakin uutta. Pahimmassa tapauksessa sopeuttava koulutus voi tuottaa tyytyväisiä ja siten rauhallisia "alamaisia", jolloin olemassa olevat valtarakenteet ja toimintamallit säilyvät.

\section{Muutosretoriikan ja käytännön välinen kuilu}

Vapaan sivistystyön vaikutukset tuntuisivat liittyvän pääasiassa sosiaalisen rakenteen vahvistamiseen, kuten Schuller (2002) toteaa, tai kriittisemmin ilmaisten sosiaalisen kontrollin vahvistamiseen, sopeuttaahan se kansalaiset selvästi esimerkiksi epäinhimillisen työelämän oravanpyörään tarjoamalla vastapainoksi työssä jaksamista tukevia onnistumisen elämyksiä. Samalla tavalla edellä todennettu sosiaalisen pääoman ja aktiivisen kansalaisuuden lisääntyminen voidaan nähdä myös sopeuttavina ilmiöinä, sillä etenkin Putnamin (2005) määritelmän mukaan sosiaalinen pääoma on yhteiskuntarauhaa turvaava ilmiö. "Aktiivinen kansalaisuus" saattaa redusoitua nykyistä poliittista järjestelmää ylläpitäväksi "aktiiviseksi äänestäjäksi”, joka lisäksi kantaa lähiyhteisössään vastuuta niistä tehtävistä, joita hyvinvointivaltion alasajo on jättänyt ilman hoitajaa (esimerkiksi huoltajat lomautettujen opettajien sijaisina).

Mikäli tulosten kriittinen tulkinta on oikean suuntainen, näyttäisi siltä, että aikuiskasvatus on kadottanut (tai jättänyt kokonaan omaksumatta?) sen kriittisen ja muutokseen pyrkivän roolin, jota alan keskeinen kirjallisuus esimerkiksi yliopistoissa alan opiskelijoille korostaa. Jo Eduard Lindeman (1926; Brookfield 1983, 1984; Steward 1987) korosti kirjassaan The Meaning of Adult Education (1926), että aikuiskasvatuksella tulisi olla radikaali rooli yhteiskunnan ja demokratian edistämisessä. Freiren (1972) ajatukset kriittisestä tietoisuudesta yhteiskunnallisen muutoksen perusvoimana ovat kaikille tuttuja. Myös nykyiset ajattelijat ovat pitäneet muutoseetosta esillä, kuten esimerkiksi bell hooks (2007) korostaessaan kulttuurieroja ja gender-tematiikkaa aikuiskoulutuksessa.

Aikuiskasvatuksen retoriikan ja käytäntöjen välillä näyttäisi siis olevan suuri kuilu. Tutkijat ja alan kehittäjät käyvät muutoskeskustelua ja siirtä- vät sitä yliopistojen kurssikirjavalintojen kautta myös tuleville ammattilaisille, mutta aikuiskoulutuksen käytännöt kentällä - jopa vapaata sivistystyötä myöten - noudattavat toisenlaista tavoitteenasettelua, joka vahvistaa olemassa olevia käytäntöjä sopeuttamalla kansalaisia nykyiseen yhteiskuntaan. Muutoksen ideologia näyttäisi konkretisoituneen käytännöksi vain kehittävässä työntutkimuksessa (Engeström 1994), mutta siinäkin suuri dialektisen materialismin siivittämä vallankumous on rajattu työorganisaation muutosprosesseihin.

\section{Lähteet}

Behrman, J. \& Stacey, N. (1997). The Social benefits of education. Ann Arbor: University of Michigan Press.

Brookfield, S. (1983). Adult education and the democratic imperative: the vision of Eduard Lindeman as a contemporary charter for adult education. Studies in Adult Education. 15, 37-46.

Brookfield, S. (1984). The contribution of Eduard Lindeman to the development of theory and philosophy in adult education. Adult Education Quarterly, 34(4), 185-196.

Bourdieu, P. (1986). The forms of capital. In: John G. Richardson (ed.): Handbook of theory and research for the sociology of education. New York: Greenwood Press.

Burrell, G. \& Morgan, G. (1979). Sociological paradigms and organizational analysis. London: Heineman Educational Books.

Desjardins, R. (2008). The wider benefits of adult learning. International Encyclopedia of Education. Oxford: Elsevier.

Desjardins, R. \& Schuller, T. (2007). Understanding the social outcomes of learning. Paris: OECD.

Engeström, Y. (1994). Training for change: New approach to instruction and learning in working life. Geneva: ILO.

Feinstein, L., Hammond, C., Woods, L., Preston, J. \& Bynner, J. (2003). The contribution of adult learning to health and social capital. Wider Benefits of Learning Research Report No.8. London: Institute of Education.

Freire, P. (1972). Pedagogy of the oppressed. Harmondsworth: Penguin.

Gagne, R. (1987) (ed). Instructional technology: 
foundations. Hillsdale, N.J.; Lawrence Erlbaum Ass.

Hammond, C. (2002). What is it about education that makes us healthy? Exploring the education-health connection. International Journal of Lifelong Education, 21(06), 551-571.

Honohan, I. (2005). 'Active Citizenship in Contemporary Demoracy' in Clodagh Harris (ed.) The report of the democracy commission: Engaging citizens, the case for democratic renewal in Ireland. Dublin: TASC and Democratic Dialogue.

hooks, b. (2007). Vapauttava kasvatus. Helsinki: Kansanvalistusseura.

Hyyppä, M. (2004). Kertyykö sosiaalisesta pääomasta kansanterveyttä? Yhteiskuntapolitiikka. 2004:4. Stakes. Helsinki. 380-386

Kansalaisopistotoiminnan vaikuttavuus (2001). Kaiku-projektin I osa. Tampre: Tampereen työväenopisto.

Koivumäki, J. (2008). Työyhteisöjen sosiaalinen pääoma. Tutkimus luottamuksen ja yhteisöllisyyden rakentumisesta ja merkityksestä muuttuvissa valtion asiantuntijaorganisaatioissa. Tampereen yliopisto. Tampere.

Kumpulainen, T. (toim.) (2007). Aikuiskoulutuksen vuosikirja. Tilastotietoja aikuisten opiskelusta 2005. Opetusministeriön julkaisuja 2007:26

Lincoln \& Guba (1985). Naturalistic inquiry. Beverly Hills: Sage.

Lindeman, E. (1926/1989). The meaning of adult education. Oklahoma: Oklahoma Research Center for Continuing Professional and Higher Education.

Manninen, J. (1998). Labour market training strategies in a late modern society. In: Walther, A. \& Stauber, B. (eds.) Lifelong learning in Europe / Lebenslanges lernen in Europa, Vol. 1, Options for the integration of living, learning and working. Tubingen: Neulig Verlag.

Manninen, J. \& Luukannel, S. (2008). Omaehtoisen aikuisopiskelun vaikutukset. Vapaan sivistystyön opintojen merkitys ja vaikutukset aikuisten elämäss ä. Helsinki: VSY.

Mezirow, J. (1981). A critical theory of adult learning and education. Adult Education, 32(1), 3-24.

Mezirow, J. (1990). Fostering critical reflection in adulthood: A guide to transformative and emancipatory learning. San Francisco: Jossey-Bass.
Morgan, D. L. (1998). The focus group guidebook. Focus Group Kit 1. Thousand Oaks, CA: Sage.

Paulston, R. (Ed). (1996). Social cartography: Mapping ways of seeing social and educational change. New York: Garland.

Peltonen, M. (1985). Koulutusoppi. Otava.

Putnam, R. (1995). Bowling alone: The collapse and revival of American community. Journal of Democracy, Vol. 6 (1995) 1, 64-78.

Riihimäki, K. \& Saarenpää-Numminen, M. (2005). Kansalaisopisto - kulttuuria ja elämälaatua kuntaan. Hämeenkyrö: Kansalaistoiminnan kulttuuriyhteisöllinen vaikuttavuus -hanke.

Schuller, T., Brassett-Grundy, A., Green, A., Hammond, C. and Preston, J. (2002). Learning, continuity and change in adult life. Wider Benefits of Learning Research Report No.3. Centre for Research on the Wider Benefits of Learning. London: Institute of Education.

Silverman, D. (1993). Interpreting qualitative data. Methods for analysing talk, text and interaction. London: Sage.

Stewart, D. (1987). Adult learning in America: Eduard Lindeman and his agenda for lifelong education. Malabar: Krieger Publishing co.

Taylor, F. (1911). Principles of scientific management. New York: Harper \& Row.

Tyler, R. (1949). Basic principles of curriculum and instruction. Chicago: University of Chicago Press.

Vaherva, T. \& Ekola, J. (1987). Aikuisten opettamisen taito. Helsinki: Yleisradio.

Artikkeli saapui toimitukseen 13.1.2010. Se hyväksyttiin julkaistavaksi toimituskunnan kokouksessa 10.5.2010. 